\title{
IMPACT OF YEAST ADDITION TO DIETS OF SUCKLING AND GROWING OSSIMI LAMBS ON THEIR PRODUCTIVE PERFORMANCE
}

\author{
I. Ibrahim Abdel-Mageed and M.A. Ali \\ Department of Animal Production, Faculty of Agriculture, University of Cairo, \\ 12613, Giza, Egypt
}

\section{SUMMARY}

Two experiments were carried out to study the effect of yeast addition on the productive performance of suckling and growing Ossimi lambs. In the first experiment, sixteen suckling lambs ( 8 weeks old and $8.63 \pm 0.26 \mathrm{~kg}$ live weight) were divided into two equal groups (8 each) and fed either $200 \mathrm{ml}$ of milk (S1, control) or $200 \mathrm{ml}$ of milk plus yeast, Saccharomyces cerevisiae, SC, $2 \mathrm{~g} / \mathrm{h} / \mathrm{d}$, for 8 weeks. In the second experiment, another 16 growing lambs (4 - 5 months old and $21.4 \pm 0.63 \mathrm{~kg}$ live body weight) were randomly assigned to two groups (8 each) and fed either clover hay plus concentrate feed mixture (14\% CP and $65 \%$ TDN) without (R1) or with (R2) SC, $2 \mathrm{~g} / \mathrm{h} / d$, for 90 days. At the end of the trial, four animals from each group were used in digestibility trials.

The data of suckling lambs showed that there was insignificant increase in the average daily gain by $7.26 \%$ for lambs in S2 compared with those in S1. Addition of yeast to the growing lambs diet $(R 2)$ significantly $(P<0.05)$ improved the digestibility coefficients of $C P$ and $C F$ by 6.71 and $4.88 \%$, respectively compared with control (R1). There was insignificant improvement in the digestibility coefficients of DM, $O M, E E$ and NFE for lambs fed $R 2$ (82.55, 85.76, 86.44 and 88.15\%) compared with those fed R1 (79.90, 83.61, 84.85 and 87.68\%). The nutritive value as TDN and DCP was significantly $(P<0.05)$ improved with yeast supplementation in $R 2$ being 78.24 and $10.74 \%$, respectively compared with $R 1 ; 74.76$ and $10.42 \%$ in the same order. There were no significant effects of yeast supplementation on ruminal $\mathrm{pH}, \mathrm{NH}_{3}-\mathrm{N}$ and $V F A$ 's being respectively, 6.27, 25.37 and 3.74 for $R 1$ vs. 6.40, 25.27 and 3.59 for $R 2$. There was a significant $(P<0.05)$ improvement in the average daily gain by $27 \%$ with yeast addition in R2. Feed conversion ( $g$ DMI/ $g$ gain), was better in R2 than R1 being 5.14 vs. 6.21 , respectively.

From the economical point of view, supplementing suckling lambs with yeast increased the net profit by LE 16.8. While adding yeast to growing lambs diet reduced the feed cost $/ \mathrm{kg}$ gain by 17\% compared with the control group, which enhanced its net profit by LE 87.5 / lamb. The results indicates the importance of adding yeast to rations of growing lambs to increase the economic efficiency and optimizing net profit of sheep flocks. Therefore, it could be concluded that, adding yeast to growing lambs rations is more efficient than administrating it to lambs before weaning.

Keywords: Sheep, Ossimi, yeast, growth rate, economic efficiency

Issued by The Egyptian Society of Animal Production 


\section{INTRODUCTION}

In Egypt, there is a gap between the available feedstuffs and farm animal feed requirements which was estimated as a shortage of 3.1 million tons of TDN per year (Fayed et al., 2009). Therefore, it is important to find more proper and cost-effective feeding systems for enhancing growth rates of fattened lambs which contribute a valid source of red meat in Egypt (Abdel-Moneim, 2009). Hence, many efforts have been made to use non-traditional feeds (El-Kady et al., 2008, Fayed et al., 2009 and Mousa, 2011) or otherwise adding probiotics to rations of lambs (Abo Ward et al., 2008, Fayed et al., 2009 and Mukhtar et al., 2010).

At the same time, the progressive reduction in use of antibiotic as growth promoters created interest in the corporation of microbial strains in animal feed to replace antibiotics. Currently, considerable attention is being given to use probiotic in animal feeding programs. Currently, two main types of probiotics based on either yeast (Saccharomyces cervisuae) or fungal (Aspergillus oryzae) cultures, solely or in combination with other microorganisms, are available for use in animal rations (Frumholtz et al., 1989). Probiotics have been used in small amounts as supplements in animal feeds for improving their performance (Dawson, 1993; Beauchemin et al., 2003 and Krehbiel et al., 2003). Moreover, many of the beneficial productive responses associated with using probiotic supplements can be directly related to their effects on the microbial population in the digestive tract (Dawson, 1993). Probiotics regulate the microbial environment of the intestine, decrease digestive disorders, inhibit pathogenic intestinal microorganisms and improve feed conversion efficiency and health performance of the host animals.

Anadan et al. (1998), mentioned that the average daily gain of Cheghu crossbred kids was improved by $38.9 \%$ with probiotic supplementation compared with unsupplemented kids. While, in the case of suckling animals, the addition of probiotics would be of great usefulness probably because its antigenic stimulation would favor the maturation of immune system thus preventing infection (Perdigon and Alvarez, 1992).

This study aimed to investigate the effect of yeast in diets, as a probiotic, on the growth performance of suckling and growing lambs.

\section{MATERIALS AND METHODS}

\section{Animals and feeding:}

Thirty-two Ossimi lambs, related to a commercial sheep flock located in Delta region, were used to study the impact of yeast addition on growth and economic performances, before and after weaning. Two experiments were carried out at the same time. In the first, sixteen suckling lambs ( 8 weeks old and $8.63 \pm 0.26 \mathrm{~kg}$ average live body weight) were divided into two equal groups ( 8 each), according to their body weight, and randomly assigned to feding either $200 \mathrm{ml}$ of milk without (control, S1) or with (S2) yeast (Saccharomyces cerevisiae, SC, Star Yeast, ICC, Brazil), 2 $\mathrm{g} / \mathrm{h} / \mathrm{d}$, for 8 weeks. Lambs were weighed weekly during the experiment period to calculate the average daily gain (ADG). In the second trial, sixteen growing lambs (4 - 5 months old and $21.4 \pm 0.63 \mathrm{~kg}$ average live body weight) were randomly assigned to two feeding groups ( 8 each) one was fed either clover hay plus concentrate feed mixture (14\% CP and $65 \% \mathrm{TDN})(\mathrm{R} 1)$ and the second was fed the same feed with 2 $\mathrm{g} / \mathrm{h} / \mathrm{d}$ yeast for 90 days. Animals were fed the concentrate feed mixture (CFM), at $2 \%$ 
of their live body weight, twice daily at 8:00 am and 15:00 pm. While, clover hay $(\mathrm{CH})$ was offered ad. libitum. The chemical composition of feedstuffs in this experiment was presented in Table (1). The feed residue was collected and weighed to record feed intake. Lambs were weighed weekly before morning feeding meanwhile, the amounts of CFM was modified according to the changes in body weight. Initial and final weights of lambs were used to calculate the average daily gain (ADG), total gain and feed conversion.

Table 1. Chemical composition of feedstuff used in experiment II, (\% as DM basis)

\begin{tabular}{ccc}
\hline \multirow{2}{*}{ Item } & \multicolumn{2}{c}{ Experimental feedstuff } \\
\cline { 2 - 3 } & Concentrate feed mixture $(\mathrm{CFM})^{*}$ & Clover hay $(\mathrm{CH})$ \\
\hline OM & 90.20 & 87.83 \\
$\mathrm{CP}$ & 14.02 & 11.99 \\
$\mathrm{EE}$ & 2.25 & 1.75 \\
$\mathrm{CF}$ & 9.50 & 30.32 \\
$\mathrm{NFE}$ & 64.43 & 43.77 \\
Ash & 9.80 & 12.17 \\
\hline *CFM consists of $40 \%$ corn $30 \%$ cottonseed meal $25 \%$ wheat bran $3 \%$ lime stone $1 \%$ salt
\end{tabular}

*CFM consists of $40 \%$ corn, $30 \%$ cottonseed meal, $25 \%$ wheat bran, $3 \%$ lime stone, $1 \%$ salt and $1 \%$ minerals and vitamins.

\section{Digestibility trial:}

At the end of the growth trial, 4 animals from each group were used to determine the nutrients digestibility using metabolic cages. Digestibility trials were conducted for, 3 days preliminary period followed by 7 days collection period. During total collection period urine was collected in bowls and feces was collected in polyethylene bags fixed to the rear of lambs. Feces and urine were collected once daily before morning feeding and representative samples were collected and stored at $-20^{\circ} \mathrm{C}$ for further analysis. Urine samples were acidified with $50 \% \mathrm{H}_{2} \mathrm{SO}_{4}$ during collection to avoid $\mathrm{N}$ lose (Nisa et al., 2004). At the end of the end of the collection period, urine and fecal samples from individual pens were thawed and mixed together to make samples for individual lambs pen and homogenized. Composite samples of feces were dried at $55^{\circ} \mathrm{C}$ for $96 \mathrm{~h}$ and ground to $1 \mathrm{~mm}$ particles.

\section{Rumen activity:}

At the end of each digestibility trial, rumen liquor samples were taken from animals via polyethylene stomach tube before morning feeding and at 2 and $4 \mathrm{hrs}$ after feeding. The samples were filtered through three layers of cheese cloth to get clear liquid to immediately determine $\mathrm{pH}$ value, then samples were subjected to ammonia nitrogen $\left(\mathrm{NH}_{3}-\mathrm{N}\right)$ and total volatile fatty acids (TVFA's) were determined.

\section{Chemical analysis:}

The proximate analysis of feeds and feces and urine nitrogen were carried out following the conventional methods of A.O.A.C. (1995). The ruminal ammonia concentration was determined according to Conway (1957) and the ruminal volatile fatty acids concentration was determined according to Warner (1964).

\section{Economic evaluation:}

Economic evaluation was based on market prices at the beginning of the experiment at May 2010. The farm gate prices were 15 L.E./ $1 \mathrm{~kg}$ yeast, 1500 L.E./ 
1ton concentrate feed mixture, 1000 L.E./ 1 ton clover hay and 30 L.E. / $\mathrm{kg}$ of live lambs.

\section{Statistical analysis:}

Data were statistically analyzed using the general linear model of SAS (1998). Multiple range test Duncan (1955) was used to test the significance difference between means.

\section{RESULTS AND DISCUSSION}

\section{Experiment I.:}

Data concerning the effect of yeast addition on growth performance of suckling lambs are presented in Table 2. There was insignificant increase in the average daily gain by $7.26 \%$ for lambs in S2 compared withS1. This result agree with findings of Abdelrahman (2010) that newborn Awassi lambs given 2 doses of direct feed microbes were $24.8 \%$ higher in average daily gain than those in the control group. This increase in the average daily gain might be due to that probiotics addition improved the protection against pathogenic intestinal microorganisms meanwhile, decreased digestive disorders.

Table 2. Effect of yeast addition in milk on growth performance of suckling lambs

\begin{tabular}{|c|c|c|c|}
\hline \multirow{2}{*}{ Item } & \multicolumn{2}{|c|}{ Experimental groups } & \multirow{2}{*}{$\pm \mathbf{S E}$} \\
\hline & S1 & S2 & \\
\hline \multicolumn{4}{|l|}{ Live body weight } \\
\hline Initial live weight, $\mathrm{kg}$ & 8.37 & 8.88 & 2.01 \\
\hline Final live weight, $\mathrm{kg}$ & 15.81 & 16.88 & 1.95 \\
\hline Total gain, $\mathrm{kg}$ & 7.44 & 8.00 & 1.05 \\
\hline Average daily gain, g/day & 124 & 133 & 25.00 \\
\hline
\end{tabular}

S1: control group $\quad$ S2: yeast treatment group

\section{Experimen II.:}

Effect of yeast addition on nutrients digestibility, feeding value and nitrogen balance are presented in Table (3).

\section{Digestion coefficients:}

Data indicated that yeast addition in $\mathrm{R} 2$ significantly $(\mathrm{P}<0.05)$ improved the digestibility coefficients of $\mathrm{CP}$ and $\mathrm{CF}$ by 6.71 and $4.88 \%$, respectively compared with control diet (R1). These results are in agreement with the findings of Abd ElGhani (2004), Ali (2005) and Mukhtar et al. (2010). The improvement of digestion coefficients might be attributed to the increase in the number of rumen cellulolytic bacteria due to yeast addition (Fayed, 2001 and Titi et al., 2008). There was insignificant improvement in the digestibility coefficients of DM, OM, EE and NFE for lambs fed R2 compared with those fed R1 being 82.55, 85.76, 86.44 and $88.15 \%$ and $79.90,83.61,84.85$ and $87.68 \%$, respectively. These results are in agreement with the findings of Angeles et al. (1998) and Garcia et al. (2000). The nutritive value of experimental diets as TDN and DCP was significantly $(\mathrm{P}<0.05)$ improved with yeast addition in R2, being 78.24 and $10.74 \%$, respectively compared with R1; 
74.76 and $10.42 \%$ in the same order. This improvement of nutritive value with yeast addition is referred to the improvement of nutrient digestion. The same trend was noticed in nitrogen balance, being 3.83 and $4.89 \mathrm{~g}$ for R1 and R2, respectively. This result is in agreement with the findings of Lee et al. (2000) and Ali (2005).

Table 3. Digestion coefficients, nutritive value and nitrogen balance of growing lambs fed tested rations.

\begin{tabular}{cccc} 
Item & \multicolumn{2}{c}{ Tested rations } & \multirow{2}{*}{ \pm SE } \\
\cline { 2 - 3 } & $\mathrm{R} 1$ & $\mathrm{R} 2$ & \\
Digestion coefficients, \% & & & \\
DM & 79.90 & 82.55 & 2.15 \\
OM & 83.61 & 85.76 & 1.95 \\
CP & $77.46^{\mathrm{b}}$ & $82.66^{\mathrm{a}}$ & 2.10 \\
EE & 84.85 & 86.44 & 1.99 \\
CF & $72.99^{\mathrm{b}}$ & $76.55^{\mathrm{a}}$ & 1.95 \\
NFE & 87.68 & 88.15 & \\
Nutritive value, \% & & & \\
Total digestible nutrients, TDN & $74.76^{\mathrm{b}}$ & $78.24^{\mathrm{a}}$ & \\
Digestible crude protein, DCP & $10.42^{\mathrm{b}}$ & $10.74^{\mathrm{a}}$ & 0.12 \\
\hline Nitrogen balance & & & \\
Nitrogen intake, g/h./d. & 10.10 & 10.09 & \\
Feces nitrogen, g/h./d. & 2.28 & 1.75 & \\
Urine nitrogen, g/h./d. & 3.99 & 3.45 & \\
Nitrogen balance, g & $3.83^{\mathrm{b}}$ & $4.89^{\mathrm{a}}$ & 0.25 \\
\hline
\end{tabular}

$\mathrm{a}, \mathrm{b}$ Means on the same row with different superscripts are significantly different $(\mathrm{p}<0.05)$.

R1: control group $\quad$ R2: yeast supplemented group

\section{Rumen parameters:}

Data in Table (4) indicated that there were no significant effects of yeast addition on ruminal $\mathrm{pH}, \mathrm{NH}_{3}-\mathrm{N}$ and VFA's being, 6.27, 25.37 and 3.74 for $\mathrm{R} 1$ vs. 6.40, 25.27 and 3.59 for R2, respectively. These results agree with that obtained by El-Badawi et al. (1998), Arcos-Garcia et al. (2000) and Ali (2005). While, in other experiments, the addition of probiotic increased ruminal $\mathrm{pH}$ and $\mathrm{NH}_{3}-\mathrm{N}$ (Williams et al., 1991 and Ayala et al., 1992) while they decreased in other experiments (Mutsvangwa et al., 1992 and Moloney and Drennan, 1994).

\section{Growth performance:}

Results concerning growth performance of growing lambs are presented in Table (5). There were significant $(\mathrm{P}<0.05)$ increases in the final live body weight $(\mathrm{kg})$, total body weight gain $(\mathrm{kg})$ and average daily gain $(\mathrm{g} / \mathrm{d})$ for lambs fed $\mathrm{R} 2$ than those fed R1 being, 35.60, 14.84 and 165 and 33.71, 11.71 and 130, respectively. The results agree with the findings of Valdes et al. (2000) and Ali (2005). This improvement in average daily gain might be due to the increase in CP digestibility (Haddad and Goussous, 2005). Moreover, yeast in R2 improved total dry mater intake (DMI) by $5.1 \%$ compared with R1. This increase in DMI with yeast addition might be due to the improvement of fermentation activity of rumen (Hughes, 1987) or to the initiation of a dynamic action which caused a faster passage rate of feed particles in the gastrointestinal tract (El-Badawi et al., 1998 and Abd-El-Ghani, 2004). 
Feed conversion (g DMI/ g gain), was better in R2 than R1 being 5.14 vs. 6.21 , respectively. This result is in agreement with that obtained by Abd-El-Ghani (2004) and Ali (2005).

Table 4. Rumenfluid $\mathrm{pH}$, ammonia $\mathrm{N}$ and volatile fatty acids of experimental lambs fed the tested rations $\mathrm{R} 1$ and $\mathrm{R} 2$

\begin{tabular}{|c|c|c|c|c|}
\hline \multirow{2}{*}{ Item } & \multirow{2}{*}{$\begin{array}{l}\text { Sampling } \\
\text { time hrs. }\end{array}$} & \multicolumn{2}{|c|}{ Tested rations } & \multirow{2}{*}{$\pm \mathrm{SE}$} \\
\hline & & $\mathrm{R} 1$ & $\mathrm{R} 2$ & \\
\hline \multirow{4}{*}{$\mathrm{pH}$} & 0 & 6.7 & 6.8 & \\
\hline & 2 & 5.7 & 5.7 & \\
\hline & 4 & 6.4 & 6.7 & \\
\hline & Mean & 6.27 & 6.40 & 0.75 \\
\hline \multirow{4}{*}{$\mathrm{NH}_{3}-\mathrm{N}, \mathrm{mg} / 100 \mathrm{ml} \mathrm{RL}$} & 0 & 22.51 & 23.74 & \\
\hline & 2 & 30.71 & 32.36 & \\
\hline & 4 & 22.89 & 19.71 & \\
\hline & Mean & 25.37 & 25.27 & 1.25 \\
\hline \multirow{4}{*}{ VFA's, mleq/mg/100 ml RL } & 0 & 2.99 & 2.79 & \\
\hline & 2 & 4.77 & 4.52 & \\
\hline & 4 & 3.54 & 3.45 & \\
\hline & Mean & 3.74 & 3.59 & 0.52 \\
\hline
\end{tabular}

Table 5. Effect of yeast addition on growth performance of growing lambs

\begin{tabular}{|c|c|c|c|}
\hline \multirow{2}{*}{ Item } & \multicolumn{2}{|c|}{ Rations } & \multirow{2}{*}{$\pm \mathrm{SE}$} \\
\hline & R1 & R2 & \\
\hline \multicolumn{4}{|l|}{ A)Live body weight: } \\
\hline Initial live body weight, $\mathrm{kg}$ & 22.00 & 20.75 & 1.55 \\
\hline Final live body weight, $\mathrm{kg}$ & $33.71^{\mathrm{b}}$ & $35.60^{\mathrm{a}}$ & 1.95 \\
\hline Total body weight gain, $\mathrm{kg}$ & $11.71^{\mathrm{b}}$ & $14.85^{\mathrm{a}}$ & 1.25 \\
\hline Daily body weight gain, $g$ & $130^{\mathrm{b}}$ & $165^{\mathrm{a}}$ & 15 \\
\hline \multicolumn{4}{|l|}{ B)Feed intake, } \\
\hline Concentrate, $\mathrm{kg} / \mathrm{h} . / \mathrm{d}$. & 0.557 & 0.564 & \\
\hline Clover hay, kg/h. /d. & 0.250 & 0.284 & \\
\hline DMI, kg / h/d & 0.807 & 0.848 & \\
\hline TDN intake, kg/h./d. & 0.603 & 0.663 & \\
\hline TDN, $\mathrm{kg} / \mathrm{kg} \mathrm{w}^{0.75}$ & 0.050 & 0.054 & \\
\hline \multicolumn{4}{|l|}{ C) Feed conversion } \\
\hline DMI, $\mathrm{g}$ feed/g gain & 6.21 & 5.14 & \\
\hline
\end{tabular}

\section{Economic evaluation:}

The economic evaluation of adding the yeast to the diet of suckling and weaned lambs is presented in table 6. Supplementing suckling lambs with yeast increased the net profit by only LE 16.8. In addition, adding yeast to the growing lambs diet 
reduced the feed cost $/ \mathrm{kg}$ gain by $17 \%$ compared with the control which increased its net profit by LE 87.5. That indicates to the benefit of adding yeast to rations of growing lambs to increase the economic efficiency and optimizing net profit of sheep flocks.

From the previous results in the first and second experiments, it could be concluded that, in feeding plans, adding yeast to either suckling or growing lambs diets had benefit effects on growth performance and economical efficiency. But adding yeast in growing lambs rations is more efficient than it's oral administration to lambs before weaning.

Table 6. Effect of adding yeast to suckling (Exp. 1) and growing lambs diets (Exp. 2) on the economic evaluation of sheep flocks

\begin{tabular}{|c|c|c|}
\hline \multicolumn{2}{|c|}{ G1 } & \multirow[t]{2}{*}{ G2 } \\
\hline Economic evaluation of Exp. I & & \\
\hline Cost of yeast / h (LE) & 0 & 1.6 \\
\hline Revenue / h (LE) & - & 16.8 \\
\hline Profit / h (LE) & - & 15.2 \\
\hline \multicolumn{3}{|l|}{ Economic evaluation of Exp. 2} \\
\hline \multicolumn{3}{|l|}{ Cost of feed intake $(L E / h / d)$} \\
\hline Concentrate & 0.84 & 0.85 \\
\hline Clover hay & 0.25 & 0.28 \\
\hline Yeast & 0.00 & 0.03 \\
\hline Feed cost / daily gain, L.E. & 1.09 & 1.16 \\
\hline Feed cost / kg gain, L.E. & 8.40 & 7.00 \\
\hline \multicolumn{3}{|l|}{ Cost through the whole exp. period $(L E / h)$} \\
\hline Cost of yeast & - & 2.70 \\
\hline Cost of G2 - G1 for concente consumption & - & 0.94 \\
\hline Cost of G2 - G1 for clover hay consumption & - & 3.06 \\
\hline Revenue / $h(L E)$ & - & 94.2 \\
\hline Profit / h (LE) & - & 87.5 \\
\hline
\end{tabular}

\section{REFERENCES}

A.O.A.C., 1995. Association of Official Analytical Chemists: "Official Methods of Analysis". $16^{\text {th }}$ Ed. Washington, DC., USA.

Abd El-Ghani A.A., 2004. Influence of diet supplementation with yeast culture (Saccharomyces cerevisiae) on performance of Zaraibi goats. Small Ruminant Research 52, 223

Abdel-Moneim A. Y., 2009. Body and carcass characteristics of Ossimi, Barki and Rahmani ram lambs raised under intensive production system. Egypt. J. of Sheep \& Goat Sciences, 4 (2), 1.

Abdelrahman M.M., 2010. Effect of direct-fed microbial (dfm) ${ }^{\circledR}$ supplements on general performance of newborn Awassi lambs. Egypt. J. of Sheep \& Goat Sciences, 5 (1), 249. 
Abou Ward G.A., M.A. Tawila, M. Sawsan, A.A. Gad and S. El-Naggar, 2008. Effect of weaning age on lamb's performance. World J. Agric. Sci., 4 (5), 569.

Ali M.A., 2005. Effect of probiotic addition on growth performance of growing lambs fed different roughages. Egypt. J. Nutr. and Feeds 8, 567.

Anadan S., A. Dey, S.M. Deb, K. Sanjay and P.C. Harbola, 1998. Effect of curds as probiotics supplement on performance of Cheghu crossbred kids. Small Ruminant Research 32 (1), 125.

Angeles S.C., G.D. Mendoza, M.A. Cobos, M.M. Crosby and F.A. CastrejoÂn, 1998. Comparison of two commercial yeast cultures (Saccharomyces cerevisiae) on ruminal fermentation and digestion in sheep fed on corn-stover diet. Small Ruminant Research 31, 45.

Arcos-Garcia J.L., F.A. Castrejo'n, G.D. Mendoza and E.P. Pe'rez-Gavila'n, 2000. Effect of two commercial yeast cultures with Saccharomyces cerevisiae on ruminal fermentation and digestion in sheep fed sugar cane tops. Livestock Production Sci. 63, 153.

Ayala O.J., S.S. Gonzalez, R. Herrera and G.D. Mendoza, 1992. Effect of a probiotic and molasses-urea supplement on fiber digestibility of sesame straw. J. Anim. Sci. 70, 304.

Beauchemin K. A., W.Z. Yang, D. P. Morgavi, G.R. Ghorbani, W. Kautz and J.A.Z. Leedlet, 2003. Effect of bacterial direct-fed microbials and yeast on site and extent of digestion, blood chemistry, and subclinical ruminal acidosis in feedlot cattle. J. Anim. Sci. 81, 1628.

Conway E.R., 1957. "Micro diffusion analysis and volumetric error". $5^{\text {th }}$ Ed. Crosby Lockwood and Sons Ltd., London.

Dawson K.A., 1993. Current and future role of yeast culture in animal production: A review of research over the last seven years. Biotechnology in the Feed Industry Proc. $9^{\text {th }}$ Annual Symposium, p 169.

Duncan D.B., 1955. Multiple range and multiple F-test. Biometrics, 11: 1.

El-Badawi A.Y., H.M. Gado and M.A. Tawila, 1998. Influence of dietary yeast culture on the lactation performance of goats. Arab. Univ. J. Agric. Sci. 6, 111.

El-Kady R.I., H.A. Abou-Zeina, H.A. Omer, F.M. Salman, M.M. Shoukry and S.M. Ahmed, 2008. Response of growing Ossimi lambs to diet containing different levels of defatted jojoba meal. American-Eurasian J. Agric. \& Environ. Sci. 4 (1), 34.

Fayed, A.M., El-Ashry, M.A. and Aziz H.A. (2009). Effect of feeding flive tree pruning by-products on sheep performance in Sinai. World J. Agric. Sci., 5 (4): 436.

Fayed M.A., 2001. Effect of using "yea-sacc" on performance of sheep and goats in Sinai. Egypt. J. Nutr. Feeds 4, 67.

Frumholtz P.P., C.J. Newbold and R.J. Wallace, 1989. Influence of Aspergillus oryzae extract on the fermentation of a basal ration in the rumen simulation technique. J. Agric. Sci. Camb. 113, 169.

Garcia C.C.G., M.G.D. Mendoza, M.S. Gonzalez, P.M. Cobos, C.M.E. Ortega and L.R. Ramirez, 2000. Effect of a yeast culture (Saccharomyces cerevisiae) and monensin on ruminal fermentation and digestion in sheep. Anim. Feed Sci. Tech. $83,165$. 
Haddad S.G. and S.N. Goussous, 2005. Effect of yeast culture supplementation on nutrient intake, digestibility and growth performance of Awassi lambs. Anim. Feed Sci. Tech. 118 (3-4), 343.

Hughes J., 1987. Yeast culture applications in calf and dairy diets. "A brief appraisal. In: T.P. Lyons (Ed.) Biotech. In the feed industry". Pp 143. Alltech Technical Puplications, Nicholsville, KY., USA.

Krehbiel C.R., S.R. Rust, G. Zhang and S. E. Gilliland, 2003. Bacterial directfed microbials in ruminant diets: performance response and mode of action. J. Anim. Sci. 81, 120.

Lee S.S., J.K. Ha and K.J. Cheng, 2000. Influence of an anaerobic fungal culture additionon in-vitro ruminal fermentation and nutrient digestion. Anim. Feed Sci. Tech. 88 (3-4), 201.

Moloney A.P. and M.J. Drennan, 1994. The influence of the basal diet and the effect of yeast culture on ruminal fermentation and digestibility in the steers. Anim. Feed Sci. Tech. 50, 55.

Mousa M.R.M., 2011. Effect of feeding Acasia as supplements on the nutrient digestion, growth performance, carcass traits and some blood constituents of Awassi lambs under the condition of north Sinai. Asian J. Anim. Sci. 5 (2), 102.

Mukhtar N., M. Sarwar, M.U. Nisa and M.A. Sheikh, 2010. Growth response of growing lambs fed on concentrate with or without ionophores and probiotics. Int. J. Agric. Biol. 12, 734.

Mutsvangwa T., I.E. Edwards, J.H. Topps and G.F.M. Peterson, 1992. The effect of dietary inclusion of yeast culture (Saccharomyces cervisiae) on pattern of rumen fermentation, food intake and growth of intensively fed bulls. Anim. Prod. 55, 35.

Nisa M., M. Sarwar and M.A. Khan, 2004. Influence of ad libitum feeding of urea treated wheat straw with or without corn steep liquor on intake, in situ digestion kinetics, nitrogen metabolism and nutrient digestion in Nili-Ravi buffalo bulls. Australian J. Agric. Res. 55, 235.

Perdigon G. and S. Alvarez, 1992. Probiotics and immune status. In: "Probiotics, Roy Fuller", Chapman\& Hall. pp 146.

SAS, 1998. Users guide statistics. Version 6, 4th ed., vol. 2, SAS Institute, Inc., Cary. NC. USA.

Titi H.H., R.O. Dmoura and A.Y. Abdullah, 2008. Growth performance and carcass characteristics of Awassi lambs and Shami goat kids fed yeast culture in their finishing diet. Anim. Feed Sci. Tech. 142, 33.

Valdes C., M.D. Carro, M.J. Ranilla and J.S. Gonzalez, 2000. Effect of forage to concentrate ratio in complete diets offered to sheep on voluntary feed intake and some digestive parameters. J. Anim. Sci. 70, 119.

Warner A.G.I., 1964. Production of volatile fatty acids in the rumen. Methods of Measurement. Nut. Abst. and Rev. 34, 339.

Williams P.E.V., C.A.G. Tait, G.M. Innes and C.J. Newbold, 1991. Effect of inclusion of yeast culture (Saccharomyces cervisiae plus growth medium) in the diet of dairy cows in milk yield and forage degradation and fermentation patterns in the rumen of steers. J. Anim. Sci. 69, 3016. 
تأثير إضافة الخميرة لغذاء الحملان الأوسيمى الرضيعة والمفطومة على أدائها الإنتاجى

$$
\text { إبراهيم إبراهيم عبد المجيد، على محمد على }
$$

قسم الإتتاج الحيوانى، كلية الزراعة، جامعة القاهرة، مصر

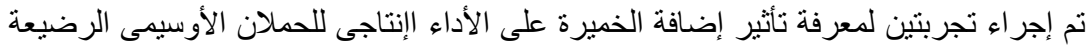

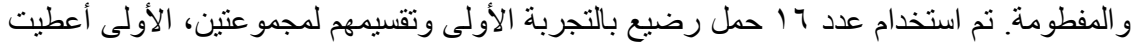

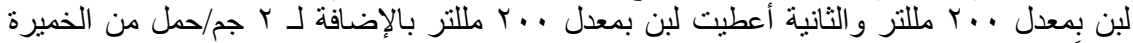

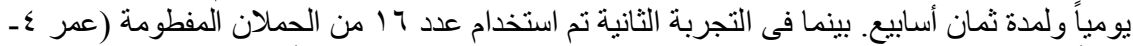

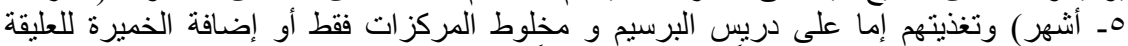

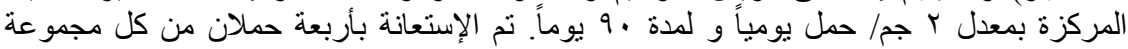

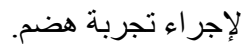

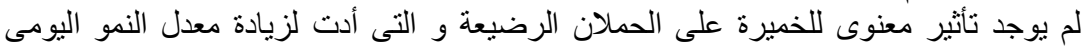

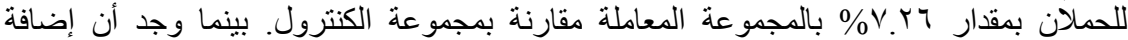

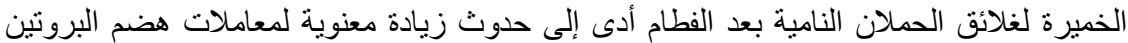

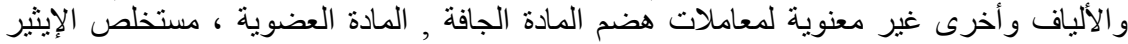

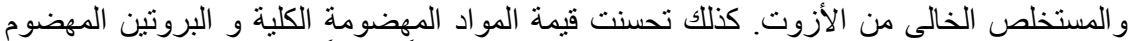

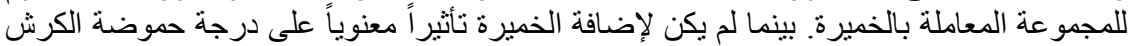

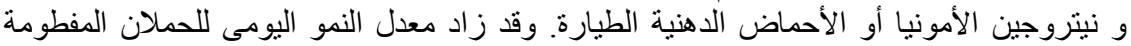
بمقدار بrV ب بإضافة الخميرة للعليقة.

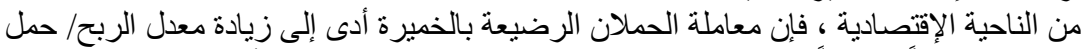

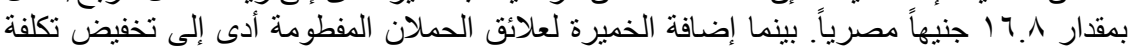

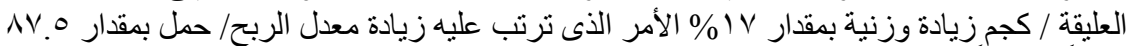

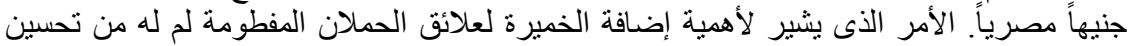
للكفاءة الإقتصادية ومن ثم تعظيم الربح للشناريع الأغنام. 